\title{
Occult Hepatitis B Virus (HBV) Infection: a Global Challenge for Medicine
}

\author{
SHOKROLLAH ASSAR ${ }^{1}$, MOHAMMAD KAZEMI ARABABADI ${ }^{1}$, \\ BEHZAD NASIRI AHMADABADI ${ }^{1}$, MANSOOR SALEHI ${ }^{2}$, DEREK KENNEDY ${ }^{3}$ \\ ${ }^{1}$ Immunology of Infectious Diseases Research Center, Rafsanjan University of Medical Sciences, Rafsanjan, Iran \\ ${ }^{2}$ Department of Genetics, Faculty of Medicine, Isfahan University of Medical Sciences, Isfahan, Iran \\ ${ }^{3}$ School of Biomolecular and Physical Science, Eskitis Institute for Cell and Molecular Therapies, Griffith \\ University,Nathan, Queensland, Australia
}

\begin{abstract}
SUMMARY
Hepatitis B virus (HBV) is a serious risk as a disease that can be spread through blood transfusion. Occult hepatitis $B$ infection (OBI) is defined in a patient with the presence of HBV-DNA but a lack of HBsAg in the serum and hepatocytes. OBI can be considered as a high potential risk factor for inducing post transfusion hepatitis (PTH), hepatocellular carcinoma (HCC), cirrhosis, and reactivation of the HBV. Recently, several investigations from various regions of the world have reported PTH as well as HCC and cirrhosis among blood recipients with diseases such as thalassemia and other disorders requiring regular hemodialysis. This form of hepatitis also causes complications for individuals that are co-infected with other viruses such as HCV and HIV. Because of its extreme disease potential, OBI can be considered a high risk for PTH, HCC, and cirrhosis. Therefore, an understanding of the prevalence of $O B I$ among blood donors is a critical strategy in most transfusion services. This review addresses the recent information regarding the prevalence of OBI worldwide, with an additional focus on Iranian blood donors.
\end{abstract}

(Clin. Lab. 2012;58:1225-1230. DOI: 10.7754/Clin.Lab.2012.120119)

\section{KEY WORDS}

Occult HBV infection, blood donors, post transfusion hepatitis

\section{INTRODUCTION}

Hepatitis B virus (HBV) is a major cause of human liver infections [1,2]. The most frequent clinical presentation of the hepatitis B is a change of the skin scleroproteins and nausea due to the increased bilirubin levels and dysfunction of liver cells $[3,4]$. Recent studies demonstrateed that many individuals are suffering from the long term forms of HBV infection including chronic, asymptomatic, and occult (OBI) hepatitis B infection [57].Although the majority of blood transfusion services are currently using ELISA techniques for the detection of HBsAg, to reduce the rate of transferring HBV infection, there are still reports of post transfusion hepatitis (PTH) [8-10]. OBI is a form of hepatitis B in which, despite of absence of HBsAg in serum, HBV-DNA is present in both serum and hepatocytes [11]. Therefore, it seems that substantial passage of PTH is by transfusion of whole blood or its components contaminated with OBI. This is highly significant for permanent recipients of blood including those with thalassemia or requiring regular hemodialysis $[12,13]$. Due to the high rate of $\mathrm{HBV}$ infection through blood transfusion from donors carrying OBI, it is important to examine and understand the prevalence of OBI in blood donors. This information will better inform blood services and help them prepare suitable diagnosis and management plans for OBI. This review draws on current reports regarding the worldwide prevalence of OBI among blood donors with an additional focus on Iranian blood donors. 
Status of OBI prevalence among blood donors in different regions of the world

The prevalence of OBI among blood donors from different countries is addressed in the Table 1 and explained in more detail in the following sections.

\section{Asia}

There are several reports regarding the prevalence of OBI among Asian blood donors. For examples Yuen et al., [3], Liu et al., [14], and Chen et al. [15] reported OBI prevalence among Chinese blood donors was $0.11 \%, 0.13 \%$ and $0.19 \%$, respectively. Other studies showed that the prevalence of OBI was between $0.001 \%$ [4] to $1.01 \%$ [16] among Japanese blood donors. Seo and colleagues from South-Korea revealed that $0.016 \%$ of the blood donors had contracted OBI [17]. Researchers also demonstrated that OBI prevalence among Pakistani [18] and Indian [19] blood donors was $0.005 \%$ and $0 \%$, respectively. The prevalence of OBI among Saudi Arabian and Omani blood donors was also evaluated by Bamaga et al. [20] and Kaminski et al. [21], respectively. They revealed that the prevalence of OBI among Saudi Arabian blood donors is 0.83 $\%$, while it is $0 \%$ for Omani blood donors [20,21]. There are several reports regarding the epidemiology of OBI among Iranian blood donors and we have collated the reports to cover three regions as follows:

\section{Status of OBI in the Northern region of Iran}

There are several provinces that are located in the Northern part of Iran where the majority of the Iranian population is living but there is limited information regarding OBI status in blood donors. To the best of our knowledge there is one report by Amini et al. regarding the prevalence of OBI among blood donors from the Tehran blood transfusion services [22] and they have shown that 5 out of $2000(0.15 \%)$ evaluated blood donors were in-fected by OBI [22]. Based on the fact that the largest population of Iranians is living in the Northern part of Iran, more studies regarding the prevalence of OBI in this region are urgently needed.

\section{Status of OBI in the Center region of Iran}

There is not enough information regarding OBI prevalence in the Center of Iran and only two studies by Sofian et al. and Pourazar et al. were reported $[23,24]$. Sofian et al. evaluated 531 blood donors in the Arak blood transfusion services [23]. Their studies demonstrated that there were no HBV-DNA ${ }^{+}$samples in the anti-HBc isolated (anti- $\mathrm{HBc}^{+} /$anti-HBs ${ }^{-}$) HBsAg negative blood donors [23]. On the other hand, our previous study on 545 blood donors from Isfahan province showed that 5 contributors $(0.9 \%)$ had HBV-DNA despite of absence of HBsAg [24]. Therefore, it seems that the range of OBI prevalence in the North and Central regions of Iran is between 0 to $0.9 \%$.

\section{Status of OBI in the Southern region of Iran}

In contrast to the Northern and Central regions of Iran, more studies were performed in the Southern region. For example, our previous study on 270 blood donors attending the Rafsanjan blood transfusion service (a city of the Kerman province) from 2007 to 2008 revealed that $4(1.48 \%)$ donors were infected with OBI [25]. Interestingly, our next study on a larger population (3700 cases) of Rafsanjanese blood donors showed that $1.54 \%$ of the HBsAg negative blood donors had detectable HBV-DNA [2]. Furthermore, another study by Behbahani et al. has shown a high prevalence of OBI in the blood donors from Shiraz (center of the Fars province) [26]. They evaluated $2000 \mathrm{HBsAg}$ and anti-HCV negative samples and in relation to the anti-HBc antibody they found that $6.55 \%$ were anti-HBc positive [26]. Behbahani et al. have shown that 16 out of 131 $(12.2 \%)$ anti-HBc positive samples were infected with HBV-DNA indicating they were OBI patients [26]. In conclusion, Behbahani et al. demonstrated that $0.083 \%$ of the blood donors in Shiraz were infected with OBI [26]. In addition, Sharifi and col-leagues performed a study on the general population of Zahedan (center of the Sistan and Baluchestan province) [27]. They reported that 3 out of 512 cases suffered from OBI [27]. Based on the fact that blood donors were derived from the general population, it could be concluded that the prevalence of OBI in the Sistan and Baluchestan provinces is $0.58 \%$. Based on these reports, it seems that the OBI is more prevalent in Iran than other Asian countries. Some possible reasons are as follow: a) Iran is in an intermediate region $(2-5 \%)$ of $\mathrm{HBV}$ prevalence [28], b) more studies were done in Iran than other countries, c) the type of HBV genotype may have an effect on the clinical presentation of hepatitis B (the common HBV genotype in Iran is type D) [29], d) differences in the studied populations in terms of genetic background, and e) PCR techniques are not used for screening of the Iranian blood donors and ELISA is used exclusively allowing the further spread of OBI. Additionally, it seems that the prevalence of post transfusion hepatitis B transmission (PTH) is different in permanent Iranian blood recipients, including thalassemic, hemophilia patients, and those undergoing regular hemodyalisis [30-32]. It seems that more studies regarding the prevalence of OBI in the Asian countries is urgently needed for transfusion services to be able to formulate an informed strategy to restrict the spread of PTH through the use of blood and its products.

\section{Europe}

Investigation in European countries showed that the OBI prevalence in Poland [33,34], Italy [34,35], Spain [34, 36], Germany [34], and Switzerland [37] were $0.0001-0.006 \%, 0.007-0.63 \%, 0.00005-0.05 \%$, $0.0006 \%$, and $0.001 \%$, respectively. Based on the reports, it can be concluded that OBI prevalence in European countries is very low. 
Table 1. The prevalence of OBI among worldwide blood donors.

\begin{tabular}{|c|c|c|c|c|c|c|c|c|}
\hline \multirow[b]{2}{*}{ Continent } & \multirow[b]{2}{*}{ Country } & \multirow{2}{*}{$\begin{array}{c}\text { Region } \\
\text { (city) }\end{array}$} & \multirow{2}{*}{$\begin{array}{c}\text { Prevalence of } \\
\text { OBI } \%\end{array}$} & \multicolumn{3}{|c|}{ Prevalence \% } & \multirow[b]{2}{*}{ Author } & \multirow[b]{2}{*}{ References } \\
\hline & & & & $\begin{array}{l}\text { Anti } \\
\text { HBc }\end{array}$ & $\begin{array}{l}\text { Anti } \\
\text { HBs }\end{array}$ & $\begin{array}{c}\text { HBs } \\
\text { Ag }\end{array}$ & & \\
\hline \multirow{4}{*}{ Africa } & Egypt & & 1.26 & 10.9 & ND & 1.1 & EI Zayadi et al. & [41] \\
\hline & Ghana & & 1.7 & ND & ND & 1.5 & Zahn et al. & [39] \\
\hline & South Africa & & 0.004 & ND & ND & ND & Allian et al. & [9] \\
\hline & Sudan & & 0.99 & ND & 56 & 36 & Mahgoub et al. & [40] \\
\hline \multirow{5}{*}{ America } & Brazil & & 0.13 & 3.6 & 1.1 & 2.6 & Almeida et al. & [43] \\
\hline & \multirow{2}{*}{ Canada } & & 0.012 & 0.53 & ND & 2.2 & Chevrier et al. & [45] \\
\hline & & & 0.52 & 1.13 & ND & ND & O'Brien et al. & [46] \\
\hline & & Inuit & 2.87 & ND & ND & ND & Minuk et al. & [42] \\
\hline & Venezuela & & $0 \%$ & ND & ND & ND & Gutierrez et al. & [44] \\
\hline \multirow{10}{*}{ Asia } & \multirow{3}{*}{ China } & & 0.11 & 0.1 & 0.07 & ND & Yuen et al. & [3] \\
\hline & & & 0.13 & ND & ND & ND & Liu et al. & [14] \\
\hline & & & 0.19 & ND & ND & ND & Chen et al. & {$[48]$} \\
\hline & India & & $\mathbf{0}$ & ND & ND & ND & Duseja et al. & [19] \\
\hline & \multirow{2}{*}{ Japan } & & 0.001 & ND & ND & ND & Yoshikawa et al. & [4] \\
\hline & & & 1.01 & 0.6 & ND & ND & Satake et al. & [16] \\
\hline & Oman & & & 20.5 & ND & 5.5 & Kaminski et al. & [21] \\
\hline & Pakistan & & 0.005 & 4.16 & ND & 2.16 & Bhatti et al. & {$[18]$} \\
\hline & Saudi Arabia & & & ND & ND & ND & Bamaga et al. & [20] \\
\hline & South Korea & & 0.016 & 13.5 & 12.2 & ND & Seo et al. & {$[17]$} \\
\hline \multirow{5}{*}{ Europe } & Germany & & 0.0006 & ND & ND & ND & Candotti et al. & [34] \\
\hline & Italy & & $0.007-0.63$ & $\begin{array}{l}\text { ND } \\
4.85 \\
\end{array}$ & $\begin{array}{l}\text { ND } \\
\text { ND } \\
\end{array}$ & $\begin{array}{l}\text { ND } \\
\text { ND } \\
\end{array}$ & $\begin{array}{l}\text { Candotti et al. } \\
\text { Manzini et al. }\end{array}$ & $\begin{array}{l}{[34]} \\
{[35]} \\
\end{array}$ \\
\hline & Poland & & 0.0001-0.006 & ND & ND & ND & $\begin{array}{l}\text { Brojer et al., } \\
\text { Candotti et al. }\end{array}$ & $\begin{array}{l}{[49]} \\
{[34]}\end{array}$ \\
\hline & Spain & & $0.00005-0.05$ & $\begin{array}{l}\text { ND } \\
\text { ND }\end{array}$ & $\begin{array}{l}\text { ND } \\
\text { ND }\end{array}$ & $\begin{array}{l}\text { ND } \\
0.05\end{array}$ & $\begin{array}{l}\text { Candotti et al., } \\
\text { Gonzalez et al. }\end{array}$ & $\begin{array}{l}{[34]} \\
{[50]}\end{array}$ \\
\hline & Switzerland & & 0.001 & 0.008 & ND & 0.007 & Stolz et al. & [37] \\
\hline
\end{tabular}

Table 1 illustrates OBI, anti-HBc, anti-HBs and HBsAg prevalence among assessed countries. ND: Not determinant.

Table 2. The prevalence of OBI among Iranian blood donors.

\begin{tabular}{|c|c|c|c|c|c|c|c|}
\hline & & \multirow{3}{*}{$\begin{array}{c}\text { Prevalence \% } \\
0.15\end{array}$} & \multicolumn{3}{|c|}{ Prevalence of OBI \% } & \multirow{3}{*}{$\begin{array}{c}\text { Author } \\
\text { Amini et al. }\end{array}$} & \multirow{3}{*}{$\begin{array}{c}\text { References } \\
{[51]}\end{array}$} \\
\hline \multicolumn{2}{|c|}{ Region (city) } & & Anti & Anti & HBs & & \\
\hline North & Tehran & & 11.5 & 8.95 & ND & & \\
\hline \multirow{2}{*}{ Center } & Arak & 0 & 2.1 & ND & ND & Sofian et al. & [23] \\
\hline & Isfahan & 0.9 & 8 & 31.8 & 0.4 & Pourazar et al. & [24] \\
\hline \multirow{4}{*}{ South } & \multirow{2}{*}{ Rafsanjan } & 1.48 & 5.18 & 1 & ND & Jafarzadeh et al. & [25] \\
\hline & & 1.54 & 9.51 & ND & ND & Arababadi et al. & {$[2]$} \\
\hline & Shiraz & 0.083 & 6.55 & ND & ND & Behbahani et al. & {$[26]$} \\
\hline & Zahedan & 0.58 & 21.5 & ND & 3.3 & Sharifi-Mood & [27] \\
\hline
\end{tabular}

Table 2 illustrates OBI, anti-HBc, anti-HBs and HBsAg prevalence among Iranian blood donors. ND: Not determinant. 


\section{Africa}

Africa is determined as having a high prevalence of HBV infection [38]. Therefore, it would be expected that the prevalence of OBI is also high among African blood donors and several investigations have confirmed this. For instance, Zahn et al. showed that $1.7 \%$ of the blood donors from Ghana are infected with OBI [39]. Allian and colleagues have evaluated 1149507 samples regarding OBI infection and they have shown that 54 $(0.004 \%)$ of the evaluated blood donors were classified as OBI in South-Africa [9]. Another study in the Sudan demonstrated that 6 out of 404 anti-HBc positive blood donors were infected with HBV-DNA, while they were HBsAg negative [40]. Therefore, it seems that the prevalence of OBI among Sudanese blood donors is $0.99 \%$ [40]. OBI was also detected in $9 / 712(1.26 \%)$ of the blood donations in the Egyptian population [41].

Based on these studies it appears that the prevalence of OBI is similar to that of Asia. Once again, more studies in the different countries within Africa would help give a more accurate picture of the prevalence of OBI in Africa.

\section{American}

Investigations from the Americas also revealed that OBI prevalence was not significantly different from other regions such as Asia and Africa. For example, Minuk et al. reported that HBV-DNA was detected in 14/487 (2.87\%) Inuit people (Canada) [42]. Brazilian investigators showed that 2 of $1536(0.13 \%)$ blood donors were infected with OBI [43]. Interestingly, Gutierrez et al. from Venezuela revealed that no OBI cases were found in 2,075 screened blood samples [44]. Studies from Canada demonstrated that the prevalence of OBI among the blood donors was 0.012 [45] to $0.52 \%$ [46]. Additionally, Kleinman et al. revealed that the rate of OBI prevalence among the USA population is as low as the Canadian population [47]. They have evaluated 231 blood donors and found that only four blood donors are infected with low levels of HBV-DNA without detectable HBsAg [47]. Based on the high population of countries in the Americans, especially southern countries, more studies among blood donors would elucidate the status of OBI among blood donors in these countries.

\section{CONCLUSION}

According to the reports mentioned above, it seems that the prevalence of OBI is frequent in blood donors worldwide, especially in Iran. One plausible reason for the high prevalence of OBI among blood donors may be related to the use of ELISA techniques to detect HBsAg. Moreover, the rate of HBV infectivity is variable between countries, hence, the differences between countries, even in the same region. Subsequently the prevalence of OBI among blood donors may be related to the rate of $\mathrm{HBV}$ infection prevalence. Previous stud- ies also reported that the HBV genotype can affect the outcome of infection, thus, another reason for the differences may be contributed to the prevalent HBV genotype varying among the countries. On the other hand, other variables may include the differences in PCR test sensitivity and the pool sizes of samples. It should be noted that many countries have not been included in this review. In some cases this reflects the lack of research into OBI in those countries. Alternatively, the medical systems do not consider DNA analysis in the detection of HBV. For example, in many Australian pathology laboratories, antigen detection is regularly used but DNA testing is an option selected by the patient s doctor and is frequently ignored. It would appear that using quantitative PCR to screen for HBV-DNA is crucial if we want to initiate a strategy that prevents further transmission of the disease. In addition, based on the high prevalence of OBI in blood donors we suggest that investigators design a follow up study to evaluate the recipients of the OBI infected blood and its components using HBV markers. Finally, the authors propose that the clinical services managers in countries with a high prevalence of OBI have a serious obligation to use complementary tests such as anti-HBc screening of blood donors in addition to using sensitive tests including quantitative and qualitative PCR to detect HBV-DNA.

\section{Acknowledgement:}

This project was supported by a grant from the Rafsanjan University of Medical Sciences and the authors declare no conflict of interest regarding the review article.

\section{Declaration of Interest:}

The authors of this manuscript have no invested interests in products described or used in this article. The authors have no conflicts of interest.

\section{References:}

1. Babaei M, Pourfarzi F, Yazdanbod A, et al. Gastric cancer in Ardabil, Irana review and update on cancer registry data. Asian Pac J Cancer Prev 2010;11(3):595-9.

2. Arababadi MK, Pourfathollah AA, Jafarzadeh A, Hassanshahi G, Rezvani ME. Association of exon 9 but not intron 8 VDR polymorphisms with occult HBV infection in south-eastern Iranian patients. J Gastroenterol Hepatol 2009 Jan;25(1):90-3.

3. Yuen MF, Lee CK, Wong DK, et al. Prevalence of occult hepatitis B infection in a highly endemic area for chronic hepatitis B: a study of a large blood donor population. Gut 2011 Oct;59(10): 1389-93.

4. Yoshikawa A, Gotanda Y, Minegishi K, et al. Lengths of hepatitis B viremia and antigenemia in blood donors: preliminary evidence of occult (hepatitis B surface antigen-negative) infection in the acute stage. Transfusion 2007 Jul;47(7):1162-71. 
5. Plymoth A, Viviani S, Hainaut P. Control of hepatocellular carcinoma through hepatitis B vaccination in areas of high endemicity: perspectives for global liver cancer prevention. Cancer Lett 2009 Dec 1;286(1):15-21.

6. Arababadi MK, Hassanshahi G, Pourfathollah AA, Zarandi ER, Kennedy D. Post-Transfusion Occult Hepatitis B (OBI): A Global Challenge for blood recipients and health authorities. Hepat Mon 2011; Article in press.

7. Arababadi MK, Pourfathollah AA, Jafarzadeh AA, Hassanshahi G. Serum levels of Interleukin (IL)-10 and IL-17A in occult HBV infected south-east Iranian patients. Hepat Mon 2010;10(1):31-5.

8. Allain JP. Occult hepatitis B virus infection: implications in transfusion. Vox Sang 2004 Feb;86(2):83-91.

9. Allain JP, Belkhiri D, Vermeulen M, et al. Characterization of occult hepatitis B virus strains in South African blood donors. Hepatology 2009 Jun;49(6):1868-76.

10. Allain JP, Candotti D. Hepatitis B virus in transfusion medicine: Still a problem? Biologicals 2012 Feb 1;2012:1.

11. .Arababadi MK, Pourfathollah AA, Jafarzadeh A, et al. Non-association of IL-12 +1188 and IFN-gamma +874 polymorphisms with cytokines serum level in occult HBV infected patients. Saudi J Gastroenterol 2011 Jan-Feb;17(1):30-5.

12. Arababadi MK, Hassanshahi G, Ahmadabadi BN, et al. Association of -592 region of IL-10 polymorphisms with asthma in south-eastern Iranian patients. Clin Lab 2011; article in press.

13. Torbenson M, Thomas DL. Occult hepatitis B. Lancet Infect Dis 2002 Aug;2(8):479-86.

14. Liu Y, Li P, Li C, et al. Detection of hepatitis B virus DNA among accepted blood donors in Nanjing, China. Virol J 2010; 7(193): 193 .

15. Trabattoni D, Schenal M, Cesari M, et al. Low interleukin-10 production is associated with diabetes in HIV-infected patients undergoing antiviral therapy. Med Microbiol Immunol 2006 Sep; 195(3):125-32.

16. Satake M, Taira R, Yugi $\mathrm{H}$, et al. Infectivity of blood components with low hepatitis B virus DNA levels identified in a lookback program. Transfusion 2007 Jul;47(7):1197-205.

17. Seo DH, Whang DH, Song EY, Kim HS, Park Q. Prevalence of antibodies to hepatitis B core antigen and occult hepatitis B virus infections in Korean blood donors. Transfusion 2011;51(8):18406. doi: 10.1111/j.1537-2995.2010.03056.x. Epub 2011 Feb.

18. Bhatti FA, Ullah Z, Salamat N, Ayub M, Ghani E. Anti-hepatitis B core antigen testing, viral markers, and occult hepatitis B virus infection in Pakistani blood donors: implications for transfusion practice. Transfusion 2007 Jan;47(1):74-9.

19. Duseja A, Sharma S, Subramanian PG, et al. Occult hepatitis B virus (HBV) infection in healthy blood donors. Indian J Pathol Microbiol 2003 Oct;46(4):690-2.

20. Bamaga MS, Azahar EI, Al-Ghamdi AK, Alenzi FQ, Farahat FM. Nucleic acid amplification technology for hepatitis B virus, and its role in blood donation screening in blood banks. Saudi Med J 2009 Nov;30(11):1416-21.

21. Kaminski G, Alnaqdy A, Al-Belushi I, Nograles J, Al-Dhahry $\mathrm{SH}$. Evidence of occult hepatitis B virus infection among Omani blood donors: a preliminary study. Med Princ Pract 2006;15(5): 368-72.
22. Aghakhani A, Banifazl M, Kalantar E, et al. Occult hepatitis B virus infection in hemodialysis patients with isolated hepatitis $B$ core antibody: a multicenter study. Ther Apher Dial 2010 Jun; 14(3):349-53.

23. Sofian M, Aghakhani A, Izadi N, et al. Lack of occult hepatitis B virus infection among blood donors with isolated hepatitis B core antibody living in an HBV low prevalence region of Iran. Int J Infect Dis 2010 Apr;14(4):e308-10.

24. Pourazar A, Salehi M, Jafarzadeh A, et al. Detection of HBV DNA in HBsAg Negative Normal Blood Donors. Iran J Immunol 2005;2(3):172-6.

25. Jafarzadeh A, Arababadi MK, Mirzaei M, Pourazar A. Occult hepatitis $\mathrm{B}$ virus infection among blood donors with antibodies to hepatitis B core antigen. Acta Med Iran 2008;46(1):27-32.

26. Behzad-Behbahani A, Mafi-Nejad A, Tabei SZ, et al. Anti-HBc \& HBV-DNA detection in blood donors negative for hepatitis B virus surface antigen in reducing risk of transfusion associated HBV infection. Indian J Med Res 2006 Jan;123(1):37-42.

27. Sharifi-Mood B, Sanei-Moghaddam E, Ghasem-Zadeh I, Khosravi S. Occult Hepatitis B virus Infection among Anti-HBc only Positive Individuals in the Southeast of Iran in high prevalence of HBV Infection Region. IIRCMJ 2009;11(1):90-2.

28. Branco F, Mattos AA, Coral GP, et al. Occult hepatitis B virus infection in patients with chronic liver disease due to hepatitis $\mathrm{C}$ virus and hepatocellular carcinoma in Brazil. Arq Gastroenterol 2007 Jan-Mar;44(1):58-63.

29. Eftekhari Y, Arababadi MK, Hakimi H, Zarandi ER. Common HBV genotype in southeastern Iranian patients. Arch Iran Med 2010;13(2):147-9.

30. Arababadi MK, Hassanshahi G, Yousefi H. HBV-DNA in hemodialysis patients infected by HCV. Saudi J Kidney Dis Transpl 2009 May;20(3):398-401.

31. Rezvan H, Abolghassemi H, Kafiabad SA. Transfusion-transmitted infections among multitransfused patients in Iran: a review. Transfus Med 2007 Dec;17(6):425-33.

32. Arababadi MK, Hassanshahi G, Yousefi H, et al. No detected hepatitis B virus-DNA in thalassemic patients infected by hepatitis $\mathrm{C}$ virus in Kerman province of Iran. Pak J Biol Sci 2008 Jul $1 ; 11(13): 1738-41$.

33. Windyga J, Brojer E, Gronowska A, et al. Preliminary results of HBV DNA testing of Polish haemophilia patients--lack of occult HBV infection. Haemophilia 2006 Jul;12(4):380-3.

34. Candotti D, Grabarczyk P, Ghiazza P, et al. Characterization of occult hepatitis B virus from blood donors carrying genotype A2 or genotype D strains. J Hepatol 2008 Oct;49(4):537-47.

35. Manzini P, Girotto M, Borsotti R, et al. Italian blood donors with anti-HBc and occult hepatitis $B$ virus infection. Haematologica 2007 Dec;92(12):1664-70.

36. Torres-Baranda R, Bastidas-Ramirez BE, Maldonado-Gonzalez $\mathrm{M}$, et al. Occult hepatitis B in Mexican patients with HIV, an analysis using nested polymerase chain reaction. Ann Hepatol 2006 Jan-Mar;5(1):34-40.

37. Stolz M, Tinguely C, Graziani M, et al. Efficacy of individual nucleic acid amplification testing in reducing the risk of transfusion-transmitted hepatitis B virus infection in Switzerland, a low-endemic region. Transfusion 2010 Dec;50(12):2695-706. 
38. Gish RG, Gadano AC. Chronic hepatitis B: current epidemiology in the Americas and implications for management. J Viral Hepat 2006 Dec;13(12):787-98.

39. Zahn A, Li C, Danso K, et al. Molecular characterization of occult hepatitis B virus in genotype E-infected subjects. J Gen Virol 2008 Feb;89(Pt 2):409-18.

40. Mahgoub S, Candotti D, El Ekiaby M, Allain JP. Hepatitis B virus (HBV) infection and recombination between HBV genotypes $\mathrm{D}$ and $\mathrm{E}$ in asymptomatic blood donors from Khartoum, Sudan. J Clin Microbiol 2010 Jan;49(1):298-306.

41. El-Zayadi AR, Ibrahim EH, Badran HM, et al. Anti-HBc screening in Egyptian blood donors reduces the risk of hepatitis B virus transmission. Transfus Med 2008 Feb;18(1):55-61.

42. Minuk GY, Sun DF, Uhanova J, et al. Occult hepatitis B virus infection in a North American community-based population. J Hepatol 2005 Apr;42(4):480-5.

43. Almeida D, Tavares-Neto J, Trepo C, et al. Occult B infection in the Brazilian northeastern region: a preliminary report. Braz J Infect Dis 2008 Aug;12(4):310-2.

44. Gutierrez C, Leon G, Liprandi F, Pujol FH. [Low impact of silent hepatitis $\mathrm{B}$ virus infection on the incidence of post-transfusion hepatitis in Venezuela]. Rev Panam Salud Publica 2001 Dec;10(6): 382-7.

45. Chevrier MC, St-Louis M, Perreault J, et al. Detection and characterization of hepatitis B virus of anti-hepatitis B core antigenreactive blood donors in Quebec with an in-house nucleic acid testing assay. Transfusion 2007 Oct;47(10):1794-802.

46. O'Brien SF, Fearon MA, Yi QL, et al. Hepatitis B virus DNApositive, hepatitis $\mathrm{B}$ surface antigen-negative blood donations intercepted by anti-hepatitis B core antigen testing: the Canadian Blood Services experience. Transfusion 2007 Oct;47(10):180915 .
47. Kleinman SH, Kuhns MC, Todd DS, et al. Frequency of HBV DNA detection in US blood donors testing positive for the presence of anti-HBc: implications for transfusion transmission and donor screening. Transfusion 2003 Jun;43(6):696-704.

48. Chen CR, Yuan Q, Ge SX, et al. [Surveillance for occult HBV infection and HBsAg variants in blood donors]. Bing Du Xue Bao 2009 May;25(3):178-84.

49. Brojer E, Grabarczyk P, Liszewski G, et al. Characterization of HBV DNA+/HBsAg- blood donors in Poland identified by triplex NAT. Hepatology 2006 Dec;44(6):1666-74.

50. Gonzalez R, Torres P, Castro E, et al. Efficacy of hepatitis B virus (HBV) DNA screening and characterization of acute and occult HBV infections among blood donors from Madrid, Spain Transfusion 2009 Jan;50(1):221-30.

51. Amini KS, Talebian A, Moghtadaie M, et al. Detection of hepatitis B virus DNA (PCR) in HBsAg negative, anti-HBc positive blood donors in Tehran province. Blood J 2004;3:379-87.

\section{Correspondence :}

Dr. Mohammad Kazemi Arababadi, Immunology of Infectious Diseases Research Center Rafsanjan University of Medical Sciences

Rafsanjan, Iran

Email : dr.kazemi@rums.ac.ir

Tel.: $\quad+983915234003-5$

Mobile: +989132926113

Fax: $\quad+983915225209$ 